\title{
VARIASI ARUS DAN SUDUT PENGELASAN PADA MATERIAL AUSTENITIC STAINLESS STEEL 304 TERHADAP KEKUATAN TARIK DAN STRUKTUR MAKRO
}

\author{
Vuri Ayu Setyowati ${ }^{1}$, Suheni ${ }^{2}$ \\ Teknik Mesin - Institut Teknologi Adhi Tama Surabaya ${ }^{1,2}$ \\ Jl. Arief Rahman Hakim 100 Surabaya, 60117 \\ Email : vuri@itats.ac.id
}

\begin{abstract}
Welding is the common method for joining material used in construction and industrial applications. Variable of welding process is the most important factor affected into the mechanical properties of welded materials. This study used Shielded Metal Arc Welding (SMAW) as welding method. SMAW method use flux to protect the metals. Sample preparations were done to make the $V$ groove using $45^{\circ}$ and $60^{\circ}$ as angle of welding. Variations of heat input also were used as 75A, 85A, and 95A. Characterization of mechanical properties was analyzed by tensile test and macroscopic analysis showed the different area after welding. Based on the following experimental result, the highest ultimate tensile strength was obtained by sample prepared $45^{\circ}$ of $V$ groove angle and $85 \mathrm{~A}$ of current which is $518 \mathrm{~N} / \mathrm{mm}^{2}$ and got $449 \mathrm{~N} / \mathrm{mm}^{2}$ of yield strength. Increasing current caused the wider weld pool in the sample surface and showed clear grove shape of welded sample.
\end{abstract}

Keywords : SMAW welding, Tensile Strength of SS 304 and SS 304L. Macroscopic analysis

\begin{abstract}
ABSTRAK
Pengelasan merupakan metode penyambungan material yang secara umum digunakan dalam bidang konstruksi maupun aplikasi di industri. Parameter pengelasan perlu diketahui karena berpengaruh terhadap sifat mekanik yang dihasilkan material setelah proses penyambungan Pada penelitian ini, proses pengelasan yang digunakan adalah Shielded Metal Arc Welding (SMAW). Pengelasan SMAW menggunakan fluks sebagai pelindung logam. Preparasi sampel dilakukan dengan pembuatan sudut pengelasan/sudut kampuh $45^{\circ}$ dan $60^{\circ}$. Arus pengelasan bervariasi sebesar 75A, 85A, dan 95A. Karakterisasi sifat mekanik diperoleh dari pengujian tarik dan pengamatan makro untuk mengetahui perubahan daerah yang berbeda setelah dilakukan pengelasan. Berdasarkan hasil pengujian, spesimen benda uji dengan sudut pengelasan $45^{\circ}$ besar beban maksimal ( $\sigma \mathrm{u})$ terjadi pada arus 85 A yaitu sebesar $518 \mathrm{~N} / \mathrm{mm}^{2}$ dan memiliki tegangan luluh paling tinggi yaitu $449 \mathrm{~N} / \mathrm{mm}^{2}$. Kenaikan arus pengelasan menyebabkan weld pool yang lebih besar dan permukaan penampang samping terlihat jelas bentuk kampuh sampel pengelasan.
\end{abstract}

Kata kunci : Pengelasan SMAW, Kekuatan Tarik SS 304 dan SS 304L, Analisa struktur makro

\section{PENDAHULUAN}

Material Austenitic stainless steel (ASS) merupakan material tahan terhadap korosi yang sering digunakan oleh industri. Sifat tahan korosi ini menyebabkan waktu penggunaan dalam jangka yang lama [1]. Penggunaan stainless steel (SS) sebagai material konstruksi di industri sering dilakuan proses penyambungan untuk membentuk komponen sesuai desain yang tepat. Penyambungan tersebut dilakukan melalui proses pengelasan. Sifat mekanik dan performa peralatan dipengaruhi proses pengelasan. Besarnya tegangan sisa akibat pemanasan dari proses pengelasan dapat menurunkan kekuatan suatu material karena adanya tegangan sisa. Hal tersebut menyebabkan material lebih mudah mengalami keretakan [2].

Penelitian ini bertujuan untuk menganalisa pengaruh arus dan sudut pengelasan pada material SS 304 terhadap kekuatan material dan pengamatan makro. Karakterisasiyang dilakukan 
untuk menjelaskan permasalahan tersebut adalah uji tarik dan proses etsa untuk mengetahui perbedaan ketiga bagian logam setelah proses pengelasan.

\section{KAJIAN PUSTAKA}

Austenitic stainless steel merupakan baja paduan yang memiliki kandungan $16-26 \% \mathrm{Cr}$, $0.75-19.0 \% \mathrm{Mn}, 1-40 \% \mathrm{Ni}, 0.03-0.35 \% \mathrm{C}$, dan kandungan $\mathrm{N}$ sebagai penstabil austenite pada temperature ruang dan kenaikan temperatur tertentu [3]. Proses perlakuan panas (heat treatment) pada austenitic stainless steels tidak dapat menaikkan kekerasan akan tetapi dapat dilakukan melalui pengerjaan dingin. Pemanasan hasil pengelasan yang dilakukan pada temperatur $427-871$ ${ }^{\circ} \mathrm{C}$ menyebabkan kromium membentuk endapan batas butir sehingga berpengaruh pada ketahanan korosi [4]. Meskipun SS adalah logam tahan korosi, akan tetapi sering terjadi korosi sumuran (pitting corrosion) maupun korosi pada batas butir (intergranular corrosion) setelah dilakukan pengelasan. Korosi jenis ini disebabkan terjebaknya logam cair yang membentuk oksida sehingga melapisi permukaan logam [5].

Penggunaan ASS dalam industri dengan proses pengelasan untuk menyambung dua bagian logam akan mengakibatkan terjadinya perubahan struktur metalurgi maupun tegangan termal. Dalam proses pengelasan SS, permasalahan utama yang terjadi adalah hasil produk las yang kasar dan getas. Selain itu, besar panas dari arus yang digunakan akan berpengaruh terhadap struktur mikro dan pertumbuhan ukuran butir dengan besarnya arus yang digunakan [6]. Panas yang digunakan untuk pengelasan akan mempengaruhi daerah logam terpengaruh panas atau yang dinamakan Heat Affected Zone (HAZ). Pada daerah HAZ mengalami siklus termal diantaranya pemanasan saat proses pengelasan berlangsung hingga proses pendinginan [7]. Perubahan secara metalurgi pada daerah HAZ mempengaruhi kekuatan dari logam. Kumar dan Shahi melakukan analisa perbedaan arus terhadap struktur mikro dan sifat mekanik. Material SS 304 dilakukan pengelasan dengan variasi arus 120A, 150A, dan 180A menggunakan metode TIG (Tungsten Inert Gas). Hasil karakterisasi menunjukkan bahwa semakin arus yang digunakan menyebabkan penurunan kekuatan pada material dan diperoleh kekuatan maksimal dari semua variabel sebesar 657,32 MPa saat arus 120A. Selain itu, kenaikan arus mengakibatkan nilai kekerasan semakin menurun dan kekerasan paling tinggi dicapai saat arus 120A yaitu sebesar 205,5-228,8 VHN [8]. Penelitian yang sudah dilakukan sebelumnya oleh Kumar dan Shahi menggunakan metode pengelasan TIG dan menggunakan arus di atas 120 A. Jeswin dan Sudhish melakukan pengelasan dengan material yang berbeda SS 304 dan AISI 1040 menggunakan metode friction welding [9]. Pengelasan menggunakan electron beam dilakukan oleh Kar, dkk untuk menganalisa struktur mikro, kekerasan dan uji impak [10]. Berdasarkan penelitian sebelumnya maka penelitian ini dilakukan pengelasan material SS tipe 304 menggunakan metode SMAW dengan arus yang lebih rendah yaitu 75A, 85A, dan 95A. Selain itu juga dilakukan analisa pengaruh variasi sudut kampuh (groove) dengan variasi $45^{\circ}$ dan $60^{\circ}$, sehingga akan diketahui parameter pengelasan yang lebih tepat untuk menghasilkan sifat kekuatan tarik yang lebih tinggi.

\section{METODE \\ Persiapan Material}

Material utama yang digunakan untuk penelitian ini adalah SS 304 yang berbentuk plat dengan ukuran $100 \mathrm{~mm}$ x $50 \mathrm{~mm}$ x $10 \mathrm{~mm}$. Material dipotong menggunakan mesin gerinda dengan aliran coolant supaya tidak terjadi perubahan struktur baik dari sifat fisis maupun komposisi kimia. Setelah proses pemotongan material, variasi sudut kampuh (groove) dibentuk pada plat SS 304 sebesar $45^{\circ}$ dan $60^{\circ}$. Adapun skema material yang akan di las ditunjukkan pada Gambar 1 di bawah ini. 


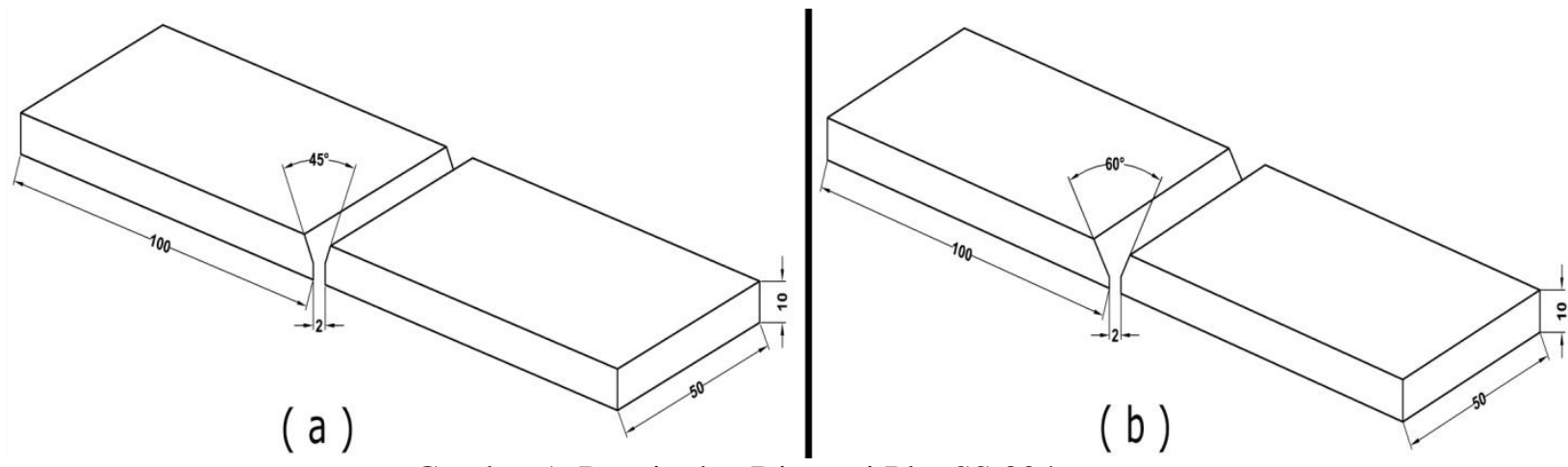

Gambar 1. Desain dan Dimensi Plat SS 304

\section{Proses Pengelasan}

Pengelasan metode SMAW menggunakan mesin las SMAW tipe ARC 400E, arus DC, dan tegangan 24 Volt. Permukaan material dibersihkan terlebih dahulu untuk mengurangi kontaminasi akibat pengotor yang terdapat pada permukaan yang akan dilas. Pengelasan menggunakan elektroda NSN 308 dengan diameter 2,6 mm. Kecepatan pengelasan diatur supaya konstan sedangan variasi arus pengelasan yang dilakukan adalah 75A, 85A, dan 95A. Skematik proses pengelasan SMAW ditunjukkan pada Gambar 2.

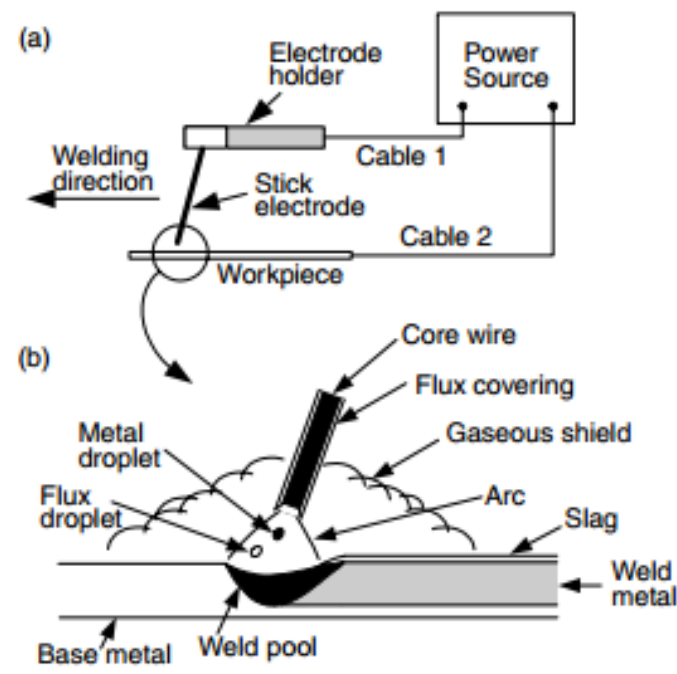

Gambar 2. Skema pengelasan SMAW (a). Secara keseluruhan (b). bagian pengelasan yang diperbesar

\section{Karakterisasi}

Pengujian material hasil pengelasan dilakukan melalui dua karakterisasi yaitu uji tarik untuk mngetahui kekuatan dan pengamatan struktur mikro untuk menganalisa lebar HAZ. Standart yang digunakan untuk pengujian tarik adalah ASTM E8. Gambar 3 menunjukkan dimensi sampel pengujian tarik pada plat SS 304.

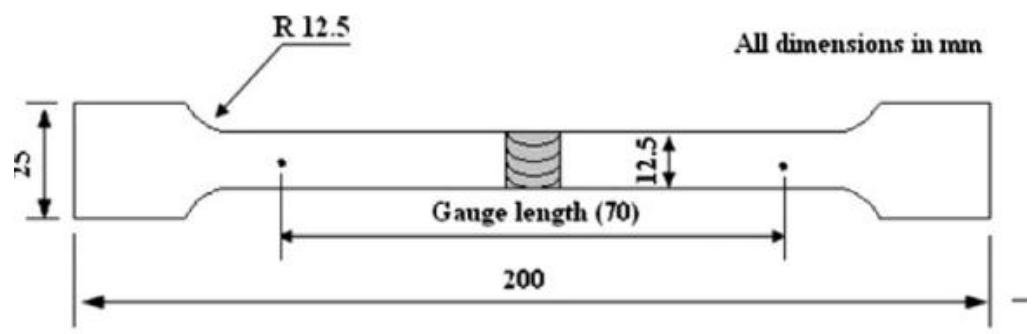

Gambar 3. Dimensi spesimen pengujian tarik untuk pelat SS 304 [8] 
Pembebanan dilakukan arah aksial hingga spesimen patah. Besarnya pembebanan dan pertambahan panjang didapatkan berupa grafik pengujian dan perlu dilakukan konversi dalam bentuk tegangan dan regangan. Selain itu dilakukan pengamatan makro untuk menganalisa daerah HAZ, logam las, dan logam induk. Material yang diuji dipotong melintang terhadap alur las. Permukaan spesimen dari material uji digosok hingga mendapatkan permukaan yang rata dan mengurangi goresan dengan menggunakan SiC paper. Pada tahap penggosokan terakhir digunakan alumina supaya permukaannya mengkilat. Selanjutnya spesimen dicelupkan ke dalam larutan etsa dengan komposisi kimia $10 \mathrm{ml} \mathrm{HNO}_{3} 10 \mathrm{ml}$ acetic acid $15 \mathrm{ml} \mathrm{HCL} 3$ tetes glycerol selama 3 menit dan setelah itu dibilas dengan air. Proses etsa metode pencelupan ditunjukkan pada Gambar 4.

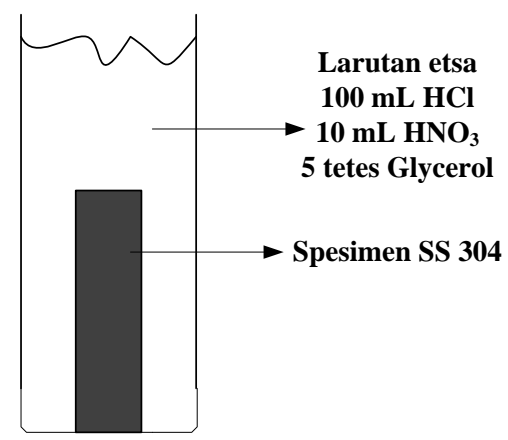

Gambar 4. Proses etsa dengan metode pencelupan

\section{HASIL DAN PEMBAHASAN}

\section{Pengaruh Arus dan Sudut Pengelasan terhadap Kekuatan Material}

Proses pengelasan pada penelitian ini digunakan variasi arus 75A, 85A, dan 95A dilakukan pengujian tarik untuk mendapatkan nilai kekuatan dari material SS 304 setelah dilakukan pengelasan. Pengujian dilakukan dengan cara pembebanan aksial hingga material uji patah. Hasil dari pengujian dikonversi menjadi hubungan tegangan dan regangan yang ditunjukkan pada Tabel 1. Pada Gambar 5 menunjukkan pengaruh arus terhadap kakuatan material $\left(\sigma_{U T S}\right)$ dengan menggunakan variasi sudut pengelasan $45^{\circ}$ dan $60^{\circ}$. Pada spesimen yang menggunakan sudut pengelasan $45^{\circ}$ akan menghasilkan kekuatan material yang lebih tinggi dibandingkan dengan sudut pengelasan $60^{\circ}$. Selain itu, parameter pengelasan yang sangat utama mempengaruhi sifat mekanik material adalah arus listrik yang digunakan.

Tabel 1. Pembebanan dan Tegangan pada Pengujian Tarik

\begin{tabular}{lcllllrr}
\hline Sudut & Arus & $\begin{array}{l}\text { Luas } \\
\left(\mathbf{~ m m}^{2}\right)\end{array}$ & $\begin{array}{l}\mathbf{P}_{\mathbf{y}} \\
(\mathbf{k g f})\end{array}$ & $\begin{array}{l}\mathbf{P}_{\text {UTS }} \\
(\mathbf{k g f})\end{array}$ & $\begin{array}{l}\mathbf{P}_{\mathbf{f}} \\
(\mathbf{k g f})\end{array}$ & $\begin{array}{l}\boldsymbol{\sigma}_{\mathbf{y}} \\
\left(\mathbf{N} / \mathbf{m m}^{2}\right)\end{array}$ & $\begin{array}{l}\boldsymbol{\sigma}_{\text {UTS }} \\
\left(\mathbf{N} / \mathbf{m m}^{2}\right)\end{array}$ \\
\hline $\mathbf{4 5}^{\mathbf{0}}$ & 75 & 100 & 43.230 & 48.130 & 46.900 & 432 & 481 \\
& 85 & 100 & 44.860 & 51.800 & 48.940 & 449 & 518 \\
& 95 & 100 & 41.190 & 44.860 & 43.640 & 412 & 449 \\
$\mathbf{6 0}^{\mathbf{0}}$ & 75 & 100 & 44.450 & 46.900 & 45.680 & 445 & 469 \\
& 85 & 100 & 43.640 & 46.490 & 44.860 & 436 & 465 \\
& 95 & 100 & 40.780 & 44.460 & 42.420 & 408 & 445 \\
\hline
\end{tabular}




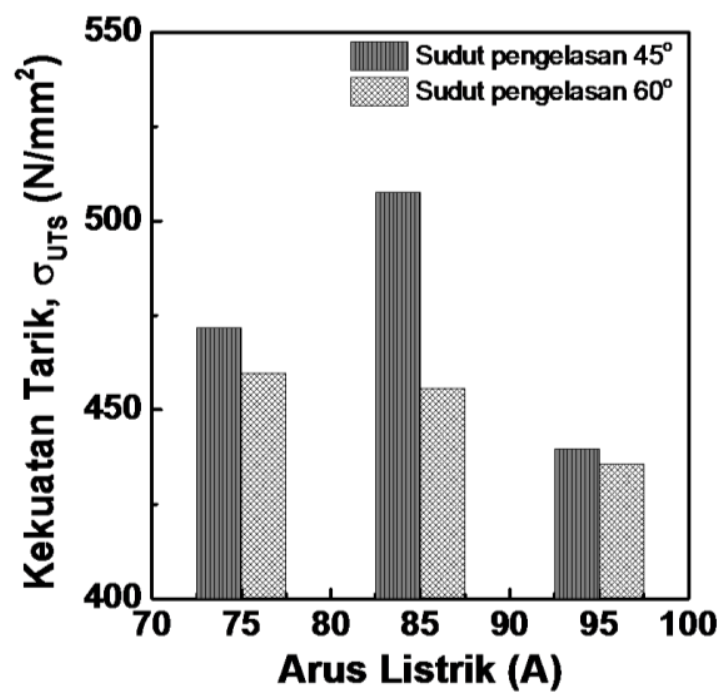

Gambar 5. Variasi Arus dan Sudut Pengelasan terhadap Kekuatan Maksimum

Gambar 5 menunjukkan kekuatan tarik material menurun dengan besarnya arus. Kekuatan tarik spesimen dengan sudut pengelasan $45^{\circ}$ dan $60^{\circ}$ memiliki nilai terendah saat arus 95A. Semakin besar arus maka ukuran dendrite pada logam las juga naik sehingga memungkinkan terjadinya pertumbuhan butir [8]. Semakin besar ukuran butir maka kekuatan dari suatu material semakin menurun disebabkan karena lebih sedikit batas butir yang menyebabkan adanya konsentrasi tegangan. Menurut penelitian yang dilakukan Yakub, bahwa semakin besar arus pengelasan untuk SS 304 akan menurunkan kekuatan tarik maksimum dan saat pengujian tarik material putus di daerah HAZ [11].

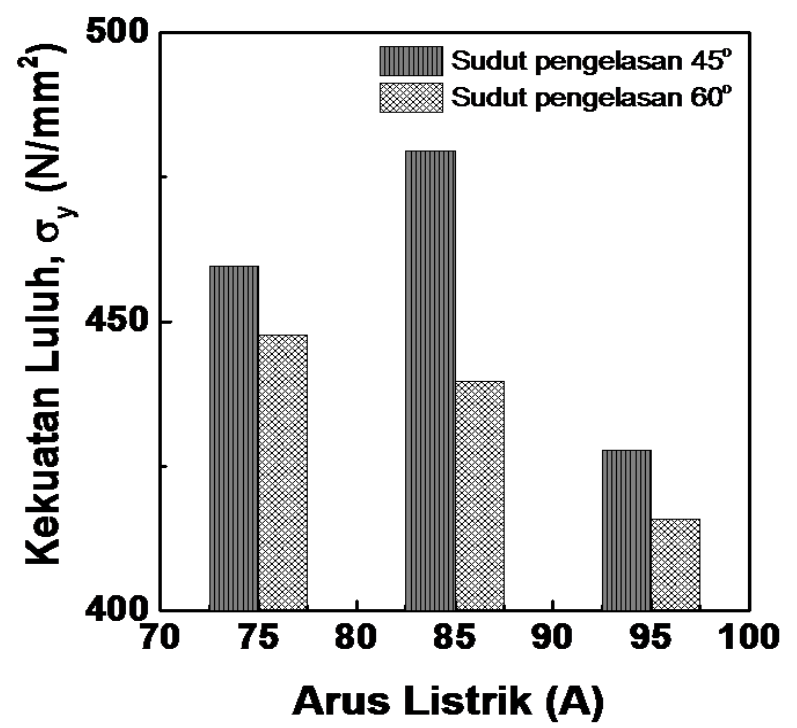

Gambar 6. Variasi Arus dan Sudut Pengelasan terhadap Kekuatan Luluh

Suatu material sambungan diketahui kekuatan luluh untuk mengidentifikasi awal sebelum material tersebut menerima beban maksimum. Hal demikian bertujuan untuk mencegah terjadinya kegagalan (fatigue) saat penggunaan material lasan. Kekuatan luluh (yield strength) pengelasan SS 304 dengan variasi arus dan sudut pengelasan ditunjukkan oleh Gambar 6. Proses pengelasan yang dilakukan dengan sudut kampuh sebesar 45 dan arus $85 \mathrm{~A}$ menghasilkan material yang memiliki kekuatan luluh paling tinggi dari variabel sampel pengujian yang lain, yaitu sebesar $480 \mathrm{~N} / \mathrm{mm}^{2}$. Semakin tinggi kekuatan luluh maka semakin sedikit distorsi yang terjadi karena material mampu untuk menahan beban yang lebih besar sebelum terjadi deformasi. Gambar 7 menunjukkan 
persentase perubahan penambahan panjang setelah pengujian tarik. Material yang sudah di las. SS 304 yang dilas dengan sudut kampuh $60^{\circ}$ pada arus 95A memiliki kekuatan luluh yang paling rendah dan persentase penambahan panjang yang paling sedikit. Hal tersebut terjadi karena arus tertinggi, 95A menyebabkan material berdeformasi saat pembebanan lebih kecil dibandingkan dengan variabel arus yang lain.

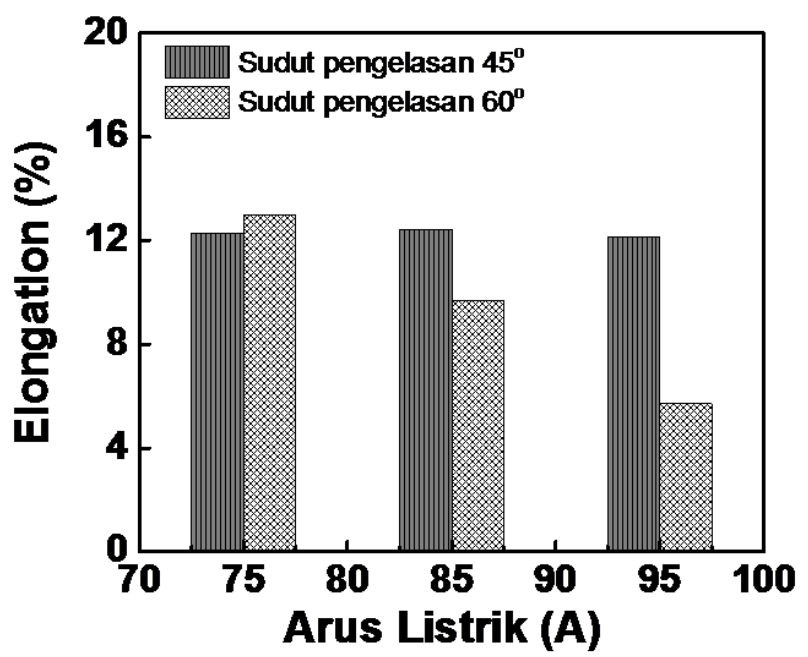

Gambar 7. Variasi Arus dan Sudut Pengelasan terhadap Elongation

Modulus elastisitas merupakan kemampuan suatu material untuk berdeformasi plastis. Berdasarkan hasil pengujian tarik diperoleh nilai modulus elastisitas seperti yang ditunjukkan pada Gambar 8. Kenaikan arus dan semakin besar sudut kampuh utnuk pengelasan SMAW pada material SS 304 menyebabkan naiknya modulus elastisitas. Pada sampel yang dilas dengan sudut kampuh $60^{\circ}$ dan arus sebesar 95A memiliki nilai modulus elastisitas yang paling besar. Hal tersebut berarti bahwa material las memiliki sifat yang lebih lentur dan tidak mampu menahan beban yang lebih besar sehingga kekuatan tarik material pada spesimen las ini paling kecil [12]. Sampel pengelasan yang memiliki modulus elastisitas paling rendah terjadi pada sampel dengan sudut kampuh $45^{\circ}$ dan dilas menggunakan arus sebesar 95A.

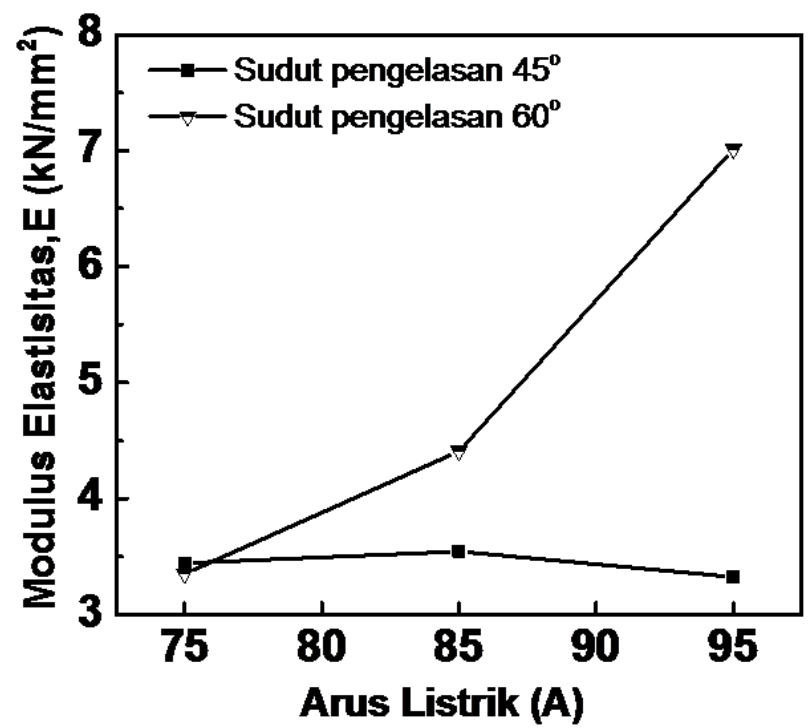

Gambar 8. Variasi Arus dan Sudut Pengelasan terhadap Modulus Elastisitas 


\section{Pengaruh Arus Pengelasan terhadap Pengamatan Makro}

Pengamatan makro merupakan pengamatan yang dilakukan untuk membedakan perubahan daerah yang terjadi setelah pengelasan berlangsung. Pada Gambar 9 ditunjukkan pengaruh arus terhadap lebar HAZ. Sudut kampuh pengelasan dibuat sebesar $45^{\circ}$. Perubahan bentuk penampang weld pool terlihat sangat jelas dengan arus yang digunakan dalam proses pengelasan. Gambar 9(a) merupakan sampel yang dilas dengan arus $75 \mathrm{~A}$ memiliki bentuk weld pool yang paling runcing dibandingkan dengan variasi arus yang lain. Sedangkan weld pool semakin terlihat saat kenaikan arus pengelasan. Gambar 9 (c) adalah sampel yang dilas dengan arus 95A memiliki bentuk weld pool yang lebar dan terdistribusi hingga bagian bawah kampuh. Semakin tinggi arus maka kedalaman penetrasi dan lebar dari logam las yang terjadi semakin besar [13]. Logam las yang mengalir dengan arus yang lebih tinggi lebih mudah mengalir dari bagian tenggah hingga terdistribusi pada setiap sudut [14].
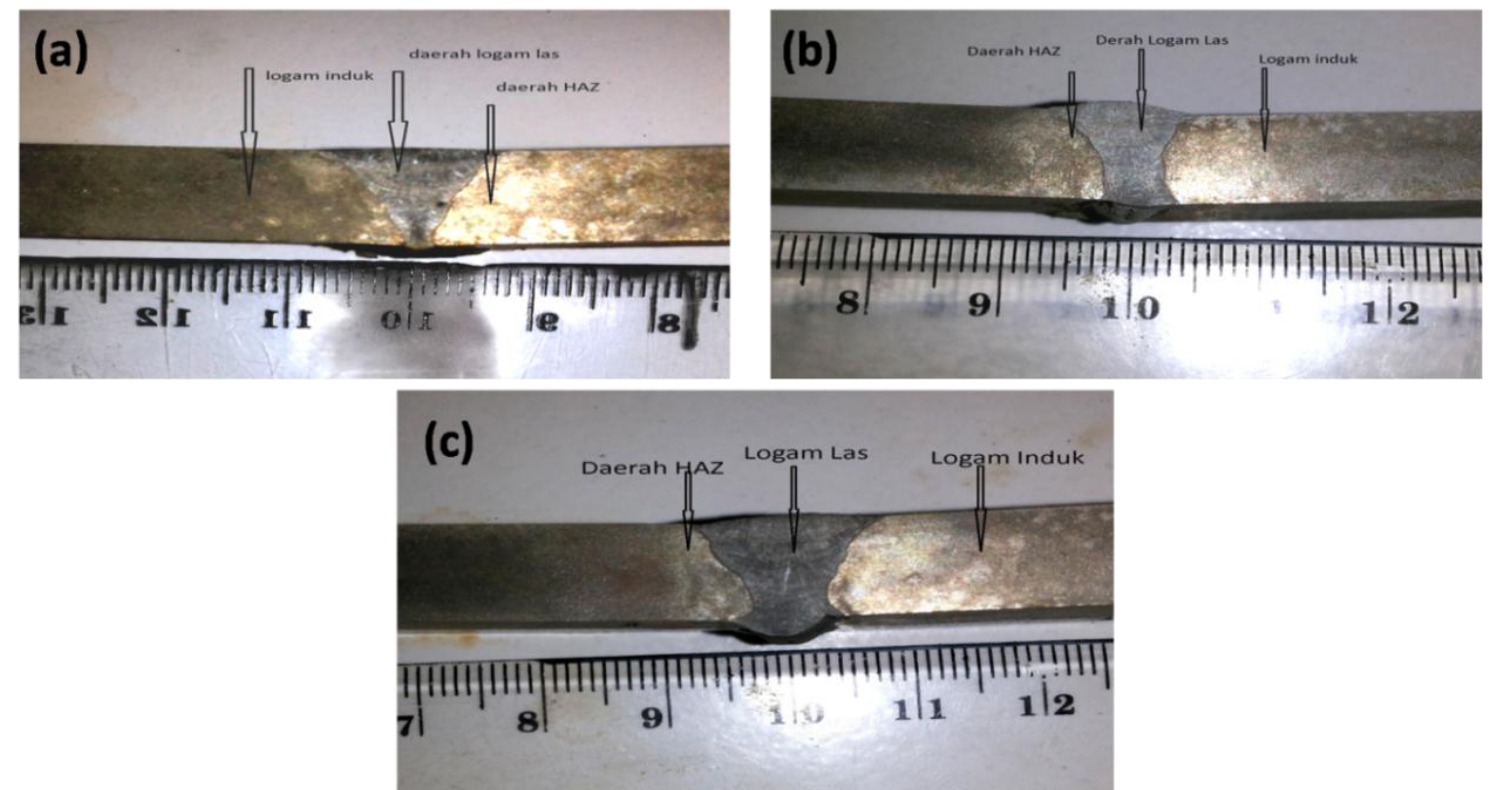

Gambar 9. Variasi Arus (a). 75A (b). 85A (c). 95A terhadap Lebar HAZ dengan Sudut Pengelasan $45^{\circ}$

\section{Pengaruh Sudut Pengelasan terhadap Pengamatan Makro}

Variasi sudut kampuh $45^{\circ}$ dan $60^{\circ}$ terhadap lebar HAZ pada pengamatan makro ditunjukkan pada Gambar 10. Terbentuknya weld pool setelah dilakukan pengelasan dengan arus $75 \mathrm{~A}$ menghasilkan bentuk weld pool yang sesuai dengan sudut kampuhnya. Akan tetapi sudut kampuh $45^{\circ}$ pada bagian samping bentuk kampuh tidak terlihat dengan jelas. Pada sudut kampuh $60^{\circ}$ pada Gambar 7 (b) mempunyai bentuk kampuh yang sangat jelas. Pengamatan makro dilakukan etsa agar variasi daerah tang terbentuk setelah pengelasan dapat terlihat.

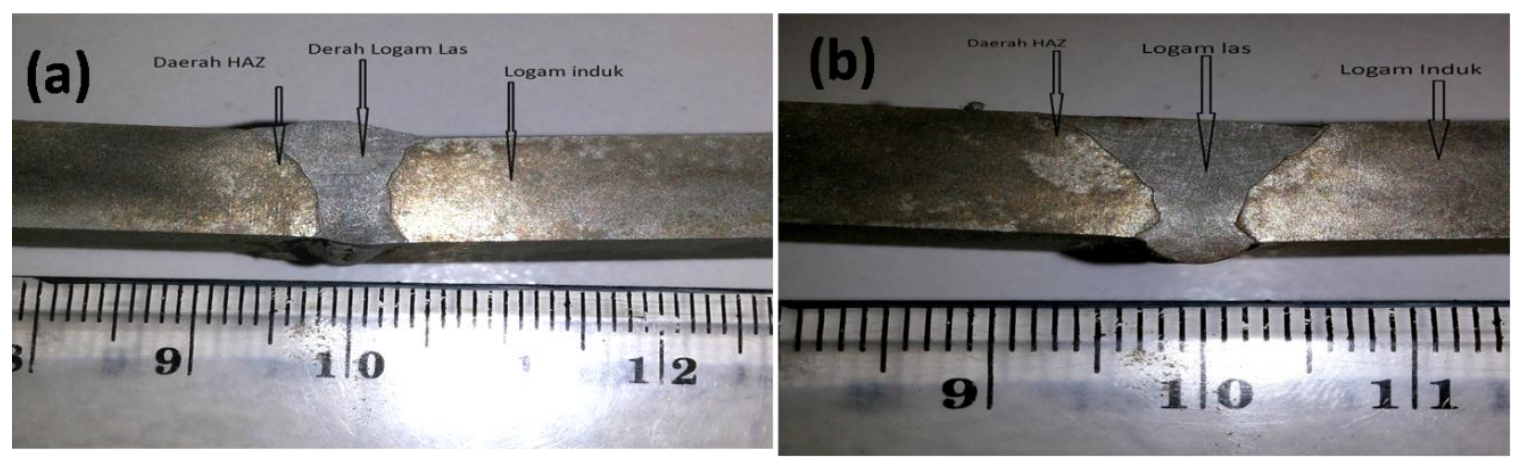

Gambar 10. Pengelasan dengan Arus 75 A saat sudut pengelasan (a) $45^{\circ}$ (b) $60^{\circ}$ 


\section{KESIMPULAN}

Berdasarkan data yang diperoleh dari pengujian, maka dapat disimpulkan bahwa :

1. Arus pengelasan SMAW berpengaruh terhadap kekuatan tarik dan kekuatan luluh suatu material. Semakin besar arus yang digunakan maka kekuatan tarik $\left(\sigma_{u}\right)$ dan kekuatan luluh $\left(\sigma_{\mathrm{y}}\right)$ material menurun. Kekuatan tarik maksimal terjadi pada sampel dengan parameter pengelasan $85 \mathrm{~A}$ dan sudut kampuh pengelasan $45^{\circ}$ yaitu sebesar $518 \mathrm{~N} / \mathrm{mm}^{2}$.

2. Sampel yang dilas dengan sudut kampuh $60^{\circ}$ memiliki kekuatan tarik dan luluh pada material yang sudah dilas lebih rendah dari pada sudut kampuh $45^{\circ}$.

3. Modulus elastisitas pada sampel dengan sudut kampuh $60^{\circ}$ lebih tinggi daripada sudut kampuh $45^{\circ}$.

4. Pengamatan makro pada sampel dengan variasi arus pengelasan 75,85 , dan 95A menghasilkan bentuk weld pool yang berbeda. Semakin besar arus maka weld pool pada bagian bawah kampuh semakin terlihat.

\section{DAFTAR PUSTAKA}

[1] Yuan,X., Chen,L., Zhao,Y., Di,H., Zhu,F. (2015). "Influence of annealing temperature on mechanical properties and microstructures of a high manganese austenitic steel". Journal of Materials Processing Technology. 217 : 278 - 285.

[2] Luder, D. Hundhausen, T. Kaminsky, E. Shor, Y. Iddan, N. Ariely, S. Yalin, M. (2016). "Failure Analysis And Metallurgical Transitions In SS 304L Air Pipe Caused By Local Overheating”. Engineering Failure Analysis. 59 : 292-303.

[3] Totten, G.E. (2006). Steel heat treatment: metallurgy and technologies. CRC press.

[4] Supriyanto, Y.A.B. (2012)."Kajian Pengaruh Tempering terhadap Sifat Fisis dan Mekanis Pengelasan Stainless Steel". Jurnal Teknik. 2.

[5] Ma, F.Y.(2012). Corrosive Effects of Chlorides on Metals, Pitting Corrosion. InTech.

[6] Zheng, H.,Ye, X., Wang, B., Liu, Z., Wang, G.(2010). "Study on microstructure of low carbon $12 \%$ chromium stainless steel in high temperature heat-affected zone". Materials \& Design. 31(10): 4836-4841.

[7] Setiawan, A. and Y.A.Y. Wardana. (2006)."Analisa Ketangguhan dan Struktur Mikro pada Daerah Las dan HAZ Hasil Pengelasan Sumerged Arc Welding pada Baja SM 490". Jurnal Teknik Mesin. 8(2): 57-63.

[8] Kumar, S., A. Shahi. (2011)."'Effect of heat input on the microstructure and mechanical properties of gas tungsten arc welded AISI 304 stainless steel joints". Materials \& Design. 32(6): 3617-3623.

[9] James, J., Sudhish, R. (2016)."Study on Effect of Interlayer in Friction Welding for Dissimilar Steels: SS 304 and AISI 1040”.Procedia Technology. 25 : $1191-1198$.

[10] Kar, J., Roy, S. k., Roy, G. (2016). "Effect of beam oscillation on electron beam welding of copper with AISI-304 stainless steel". Journal of Materials Processing Technology. 233 : $174-185$.

[11] Yakub, Y. (2013). "Variasi Arus Listrik terhadap Sifat Mekanik Mikro Sambungan Las Baja Tahan Karat AISI 304”. E-journal Widya Eksakta. 1(1).

[12] Naharuddin, N., A. Sam, dan C. Nugraha. (2015)."Kekuatan Tarik dan Bending Sambungan Las pada Material Baja SM 490 dengan Metode Pengelasan SMAW dan SAW". Jurnal MEKANIKAL. 6(1).

[13] Unnikrishnan, R., Idury, S., Ismail, T., Bhadauria, A., Skekhawat, S.K., Khatirkar, R., Sapate, S. (2014)."Effect of heat input on the microstructure, residual stresses and corrosion resistance of $304 \mathrm{~L}$ austenitic stainless steel weldments". Materials Characterization. 93:. 10-23.

[14] Tseng, K.-H. dan C.-Y. Hsu. (2011). "Performance of activated TIG process in austenitic stainless steel welds". Journal of Materials Processing Technology. 211(3): 503-512. 